\title{
A Review on Effect of Copper and Iron Nanoparticle on Agricultural Crop
}

\section{Satdev and Nintu Mandal"}

Department of Soil Science and Agricultural Chemistry, Bihar Agricultural University, Sabour, Bhagalpur, Bihar, India *Corresponding author: nintumandal@gmail.com

\begin{abstract}
Nano materials are used in practically every aspect of modern life, including agriculture. The conventional fertilizer is replacing by nano fertilizer due to its less quantity required for plant growth and development. Copper and Iron elements are essential micronutrient for plant. Nano $\mathrm{Cu}$ and Fe are playing an important role for various attributes such as growth yield, quality, and biochemical parameter. Late blight of potato caused by fungus activity of Phytophthora hence antifungal activity and phytotoxicity improved by the nano Cu. Enzymatic activity (ascorbate peroxidase (APX), catalase (CAT), superoxide dismutase (SOD), glutathione reductase (GR), and lipid peroxidation) and photosynthesis component (chlorophylls a, b and carotenoids) of plant are much influenced by application of Nano $\mathrm{Cu}$ and Fe.
\end{abstract}

Keyword: Nanomaterials, enzymatic activity, photosynthesis components

Nanotechnology may be defined as the manipulation of matter through a materials numbers and / or processes material to manufacture products with specific characteristics that can be implemented in several of applications (Usepa et al. 2007). Nanoparticles size range upto 1 to $100 \mathrm{~nm}$ in a dimension. Nanoparticles have contain special properties, special extraction, thermal and electrochemical, etc. compared to bulk materials (Panigrahi, et al. 2004).

The problem of Fe and $\mathrm{Cu}$ deficiency has been noted and is the most serious micronutrient after Zn deficiency. The micronutrient of copper and iron were govern many important role in plant as well as human being such as increase the growth, yields and quality contents of plant, while in human body $\mathrm{Cu}$ and $\mathrm{Fe}$ are incorporated into various protein and metallo-enzyms, improved the levels of leghemoglobin, $\mathrm{O}_{2}$ transferring in your blood and its necessary for the proper all over growth, developments and bone, brain and other body organs maintenances. Despite all these, the amount of major nutrients is added to the soil more than the micronutrients, due to which the fertilizer balance of the soil is deteriorated with low nutrients use efficiency the micro nutrients are unavailable for the plants, as well as the high concentration macro minerals were accumulate in food chain due to which diseases like cancer are born in human being. Generally nutrient use efficiency of micro nutrient is $3-5 \%$. Fertilizer use efficiency can be enhanced by reducing the amount of fertilizer with the help of nanotechnology.

How to cite this article: Satdev and Mandal, N. (2020). A Review on Effect of Copper and Iron Nanoparticle on Agricultural Crop. International Journal of Inclusive Development, 6(1): 31-36.

Source of Support: None; Conflict of Interest: None (c) 8 
Copper is playing very much important role in growth and developments of plant and it's positively effect on crop productivity (Karamanos et al. 2004). Additionally, $\mathrm{Cu}$ is essential to the plant growth, it is active several enzyme processes, and play an important role for formation of chlorophyll component (Viera et al. 2019). The CuO nanoparticle priming plants showed that enhanced drought tolerance indicated by their higher leaf water content and plant biomass as well as plants increased anthocyanin, chlorophyll and carotenoid contents compared under drought as compared with water-treated plants Nguyen et al. (2020). Nano $\mathrm{Cu}$ was positively influcence of germination seedling growth as well as biochemical attributes such as protein and sugar content Singh, et al. (2017). Nair and Chung (2014) CuO-NPs were applied that NPs could have vascular tissues translocated and their subsequent $\mathrm{Cu}$ ions dissolution could have rise to the observed. Application of Cu-NPs leads to increased lignification in the pericarp cell walls of the fruit due to which the firmness of tomato fruits is increased. In particular nano $\mathrm{Cu}$ based materials are positively developed specifically for applications in agricultural and food preservation based on the antifungal and antimicrobial properties of $\mathrm{Cu}^{+2}$ (Montes et al. 2015; Majumder and Neogi, 2016), and nanopesticides are based on $\mathrm{Cu}-\mathrm{NPs}$ (Keller et al. 2017).

Iron is play major role in growth, yield and biochemical function of various agriculture crops. Generally iron $(\mathrm{Fe})$ is an essential nutrient for all organisms (Zuo and Zhang, 2011). Soil particles are fixed large amount of Fe content (Mimmo et al. 2014; Bindrabanetal., 2015). High soil pH and aerobic condition cause $\mathrm{Fe}$ insoluble form $\mathrm{Fe}_{3} \mathrm{C}$ in the soil and the available form, $\mathrm{Fe}^{2+}$ (Ye et al. 2015). Fe elements are participate in many physiological processes such as chlorophyll biosynthesis, respiration, and redox reactions (Mimmo et al. 2014; Ye et al. 2015; Zargar et al. 2015). Fe deficiency not olny affects the growth and development of plants but also affect the animal and human activity and created diseases anemia (Guerinot and Yi, 1994; Li et al. 2014).

\section{Function and Deficiency symptoms of $\mathrm{Cu}$ and Fe}

\section{Copper $(\mathrm{Cu})$}

The essential micronutrients of copper is absorbed in form of $\mathrm{Cu}^{+2}$. Generally sufficient range of $\mathrm{Cu}$ for plant tissue is between 5 to $20 \mathrm{ppm}$ and the concentration below 5 ppm deficiency symptoms appear on young leaves.

\section{Functions}

1. Major important role of $\mathrm{Cu}$ for the synthesis of lignin in plant. Lignin is constituent of the cell walls that provide strength and rigidity of cell wall and essential for plant erect stature.

2. $\mathrm{Cu}$ is part of the several enzyme activity such as cytochrome oxidase that catalyzes electron transfer in the transfer of electrons in respiration.

3. Important in carbohydrate and lipid metabolism.

\section{Deficiency symptoms}

1. Young leaves become yellow and stunted.

2. In advanced stages, necrosis along leaf tips and edge appears.

3. Lodging, wilting and increased incidence of disease is observed due to reduced lignification with low $\mathrm{Cu}$.

\section{Iron $(\mathrm{Fe})$}

The Iron micronutrient are absorbed in form of $\mathrm{Fe}^{+2}$ and $\mathrm{Fe}^{+3}$ by plant root and sufficiency range upto 50 and $250 \mathrm{ppm}$. When the Fe concentration of below 50 ppm plant appearance deficiency symptoms on young leaves because it is immobile in plant.

\section{Functions}

1. Fe is major component of the porphyrin molecules, cytochrome, heme protein, Fe-S protein and leg-haemoglobin. It also involved in respiration and photosynthesis for oxidation-reduction reactions.

2. In the chlorophyll biosynthesis Fe is working as catalyst agents. It is key role in enzyme activity such as nitrogenase.

\section{Deficiency symptoms}

1. Young leaves develop interveinal chlorosis, progressing rapidly over the entire leaf. 
2. In severe cases, leaves turn entirely white and necrotic.

\section{Application of $\mathrm{Cu}$ and Fe nanoparticles on various agricultural crops}

\section{Effect of nano $\mathrm{Cu}$ and $\mathrm{Fe}$ on growth and yield attributes}

Nguyen et al. (2020) studies that application of nano $\mathrm{Cu}$ on maize crop enhances several growth and yield parameter under stress condition and normal condition. Shoot biomass days after 14 \& 21 days and shoot height of 14 days after sowing of the priming plant by Nano $\mathrm{CuO} @ 4.444 \mathrm{mg} \mathrm{L}^{-1}$ expressed higher than that of water-treated plants. There are any non significantly difference were found between other tested CuO-NPSs and control treatments. The shoot biomass of treated plant by Nano Cuo was showed (Fig. 1) less effect by drought stress as comparison with water-treated plants. plants were nano $\mathrm{CuO}$ treated showed that reduced the level of chlorophyll and carotenoids compared with $\mathrm{CuO}-\mathrm{NPs}$ treated non stressed plant but in case of water treated plant were sharp decline in the levels of chlorophyall content and carotenoids under drought stress groups as compared with water-treated non-stressed group. Sheykhbaglou et al. (2010) studies that the nano FeO at the concerntration of $0.75 \mathrm{~g} \mathrm{~L}^{-1}$ were increased leaf + pod dry weight while the application of $0.5 \mathrm{gL}^{-1}$ FeO-NPs gave highest grain yield in comparison with control. Tyagi et al. (2016) interaction of $\mathrm{ZnO}$ and $\mathrm{FeO}$ gave significant root and shoot growth of plants, supply plant nutrient and increasing cell permeability of the plants.

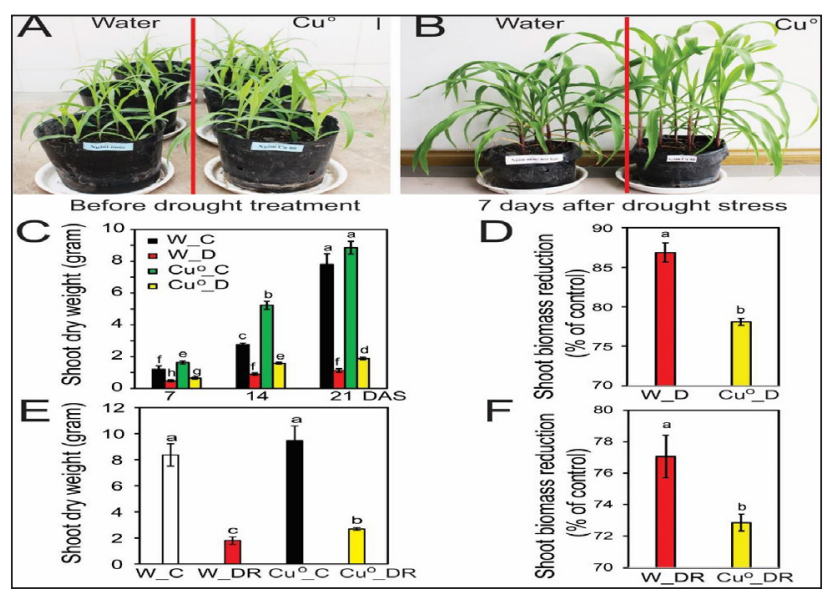

Fig. 1: Drought tolerant phenotype of the copper nanoparticle priming in maize
Armin et al. (2014) studies that the foliar application of Nano-Fe were significantly increase yield and yield components of wheat crop. The different concentration of Nano $\mathrm{Fe}_{2} \mathrm{O}_{3}\left(50-1000 \mathrm{mg} \mathrm{kg}^{-1}\right.$ ) positively affect showed (Fig. 2) on dry weight, branches number, height of shoot, root length and phenotypic parameter of peanut crop Rui et al. (2016).

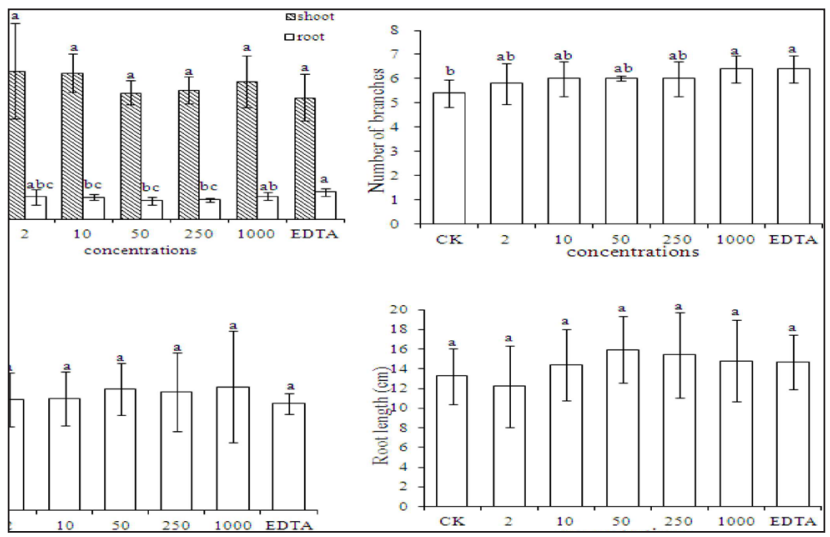

Fig. 2: Effect of $\mathrm{Fe}_{2} \mathrm{O}_{3}$ NPs or EDTA-Fefertilizer on dry weight (A) No. of branches, (B) Plant height, (C) Root length, (D) andphenotypic image, (E) of peanut

\section{Effect of foliar spraying Cu-NPs and Fe-NPs on the quality content}

Vargas et al. (2018) Tomato fruit quality such as firmness, $\mathrm{pH}$, electrical conductivity (CE), Total soluble solids (TSS) and Titratable Acidity (TA) showed statistical influenced by spraying of several concentration of $\mathrm{Cu}-\mathrm{NPs}$ The fruit firmness were increased with all foliar spraying of $\mathrm{Cu}$ NPs (50, 125,250 , and $500 \mathrm{mg} \mathrm{L}^{-1}$ ) with respect to the control treatment. Juarez-Maldonado et al. (2016) found similar result firmness of tomato fruit were increased $9 \%$ with the application of the application of $\mathrm{Cu}$ NPs + chitosan. The foliar application at the rate of 125 and $50 \mathrm{mg} \mathrm{L}^{-1}$ gave significantly higher fruit $\mathrm{pH}$ than that of the control while decrease in the titratable acidity (TA) was found in the application of $125 \mathrm{mg}$ $\mathrm{L}^{-1} \mathrm{Cu}$ NPs as comparison to the control. Generally tomato $\mathrm{pH}$ range is found between 4.0 to 4.5 . Fruit $\mathrm{pH}$ is highly influued of fruit quality and less acidic fruit are more favourable by consumers for their better Anthon et al. (2011); Jones, (2007). The Cu-NPs application was increased the electrical conductivity of tomato fruit. The lowest value were found in control treatment while application of Cu NPs @ $250 \mathrm{mg} \mathrm{L}^{-1}$ showed increases in EC of tomato fruit. In bioactive compounds which total proteins, Vit 
$\mathrm{C}$ and flavonoids were significantly influenced by various concentration of $\mathrm{Cu}-\mathrm{NPs}$. Foliar application of $\mathrm{Cu}-\mathrm{NPs} 50 \mathrm{mg} \mathrm{L}^{-1}$ were observed higher total protein content and content of flavonoids while the highest increase fruit vitamin C $(121.97 \%)$ was found in the application of $250 \mathrm{mg} \mathrm{L}^{-1}$ of $\mathrm{Cu}$ NPs compared to the control. Foliar spraying of Nano Fe significantly increase protein content in Phaseolus vulgaris (Jahanara et al. 2013).

\section{Effect of $C u$ and Fe nanoparticles on photosynthesis index}

Wang et al. (2019) Reported that the application CuONPs mixed with the soil were no significant change in $\mathrm{Chl}$ a content, intercellular $\mathrm{CO}_{2}$ concentration or photosynthetic rate in leaves of lettuce while $\mathrm{Cu}$ NPs@ $200 \mathrm{mg} / \mathrm{kg}$ were found Chl b in the lettuce leaves is decreased as compared with control. Cao et al. (2018) revealed that the chlorophyll pigments were severely reduced by the excessive $\mathrm{Cu}(120 \mu \mathrm{M}$ as $\mathrm{CuSO}_{4}$ ) resulting the lower stomatal conductance and photosynthetic rate.

Mushinskiy and Aminova (2019) studies were carried out of the various size and concentration of nanoparticles such as Fe (90-110 Nm), Cu (50-110 Nm) and Mo (100-120 Nm) nanoparticles were applied in four concentrations with a geometric progression $(0.0125 ; 0.025 ; 0.05$ and $0.1 \mathrm{M})$. The application of different concentration of nanomaterials was significantly influenced biochemical parameter (Fig. $3)$. We know that chlorophylls $a, b$ and carotenoids are playing a major role in the photosynthetic processes. Fe nanoparticles at doses of 0.0125- 0.1 $\mathrm{M}$ gave positive effect on the level of $\mathrm{Chl}$ a and $\mathrm{Chl}$ $\mathrm{b}$ in sprout of potato due to iron ions isolated from their composition.

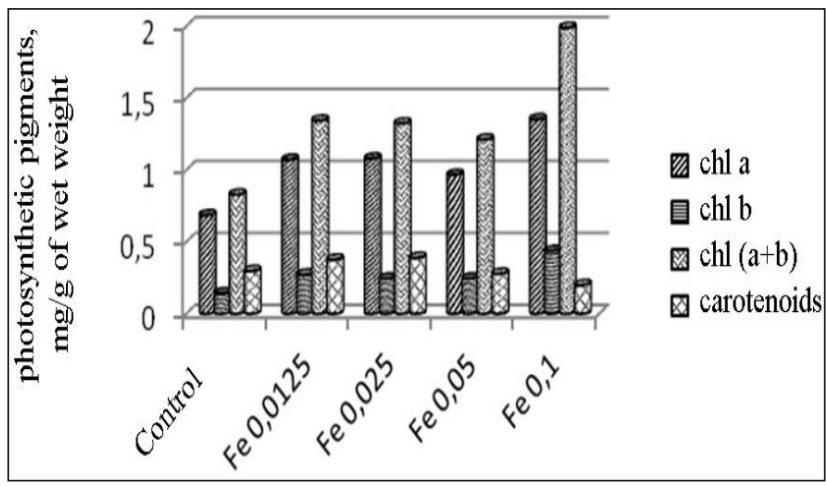

Fig. 3: The content of photosynthetic pigments in of Solánum tuberosum L. sprouts treated with suspensions of iron nanoparticles

\section{Effect of $\mathrm{Cu}$ and Fe nanoparticles on enzymatic activity}

Ogunkunlea et al. (2018) studies that the nano $\mathrm{Cu}$ was significantly impact on several enzymatic activities of Vigna unguiculata plant. The major enzymes such as activity of ascorbate peroxidase (APX), catalase (CAT), superoxide dismutase (SOD), glutathione reductase (GR), and lipid peroxidation in leaves and roots APX activity of enzyme was significantly increase recoded in the concentration of nano $\mathrm{Cu} 25 \mathrm{~nm}$ as compare to control in leaf and root tissues both while CAT activity in leaf tissue of plants exposed to $25 \mathrm{~nm} \mathrm{Cu}-\mathrm{NPs}$ decreased with compared to control, but in case of CAT activity in root, was positively increased at all the $60-80 \mathrm{~nm}$ nano- $\mathrm{Cu}$ concentration as compare to control (Fig. 4). Shaw and Hossain (2013) and Hong et al. (2015) similar evidence of the increases activity of APX in leaves by the application of nano $\mathrm{Cu}$ in Oryza sativa and Lactuca sativa respectively. Rao and Shekhawat (2016); Dimkpa et al. (2012) reported that application of nano $\mathrm{CuO}$ at the doses of $1000 \mathrm{mg} / \mathrm{L}$ and 500 $\mathrm{mg} / \mathrm{kg}$ gave significantly increase CAT enzymatic activity in Brassica juncea and Triticum aestivum. In addition, Trujillo-Reyes et al. (2014) in the root CAT activity was increased with the applied of nano $\mathrm{Cu}$ treatment but decrease APX activity in root of Lactuca sativa. All over view results showed that various activity of antioxidant enzymes deponds on plants species. Iron is a key role in structural component in many enzymes such as catalases and peroxidases as well as flavoproteins (Boorboori et al. 2012).

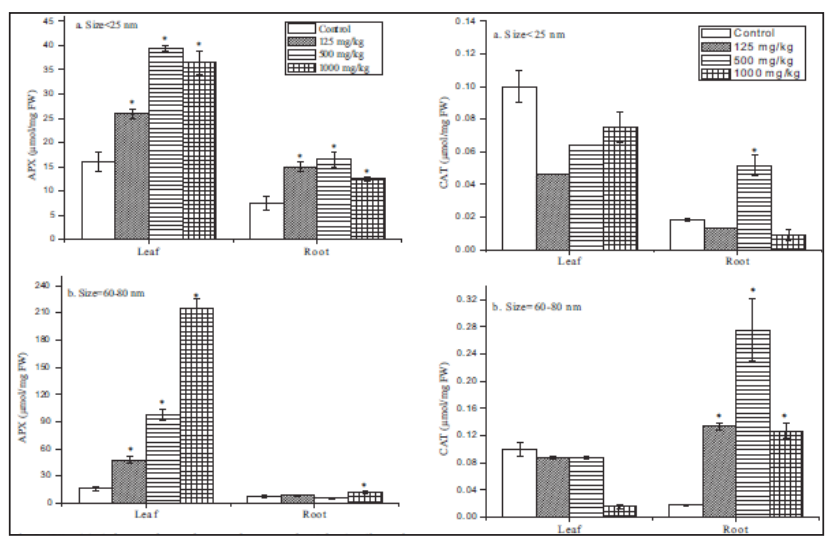

Fig. 4: APX and CAT activity in leaves and roots of cowpea plants grown for 65 days in soil treated with (a) 0 (control), $125 \mathrm{mg} / \mathrm{kg}, 500 \mathrm{mg} / \mathrm{kg}$ and $1000 \mathrm{mg} / \mathrm{kg}$ nano-Cu $(<25 \mathrm{~nm})$, and (b) 0 (control), $125 \mathrm{mg} / \mathrm{kg}, 500 \mathrm{mg} / \mathrm{kg}$ and $1000 \mathrm{mg} / \mathrm{kg}$ nano- $\mathrm{Cu}(60-80 \mathrm{~nm})$ 


\section{Effect on Cu based NPs on Antifungal activity and phytotoxicity}

Giannousi et al. (2013) the synthesized Cu-NPs by hydrothermally method using sereval chemical compound such as copper(II) nitrate trihydrate, hydrazine hydrate and polyethyleneglycol. NPs were characterized by X-ray powder diffraction (XRD), TEM images, elemental composition of the samples was tested by inductively coupled plasma atomic emission spectroscopy (ICP-AES), Thermogravimetric analysis (TGA) and Fourier transform infrared spectroscopy (FTIR). Average particles size of synthetic Cu-based NPs of 11-55 nm (Fig. 5). Phytophthora infestan caused late blight of tomato a well known threat to one of the major agricultural products world-wide. The efficacy of the nanomaterials $\mathrm{Cu} / \mathrm{Cu}_{2} \mathrm{O}$ composite NPs, $\mathrm{Cu}_{2} \mathrm{O}$ NPs and $\mathrm{CuO}$ NPs were evaluated of the anti antifungal activity against Phytophthora infestans and crop safety on protected tomato plants. Plant treated with the application three different $\mathrm{Cu}$ based NPs resulted significantly protection from the fungal disease infection from $P$. infestans on leaves as comparison to the negative control treatment. Petzold et al. (2012); Akhavan and Ghaderi (2010) studies that matallic Cu-NPs were found more bioreactive as compared to $\mathrm{Cu}_{2} \mathrm{O}$ and $\mathrm{CuO}$ NPs, and its more effective against Escherichia coli bacteria and antiviral activity.

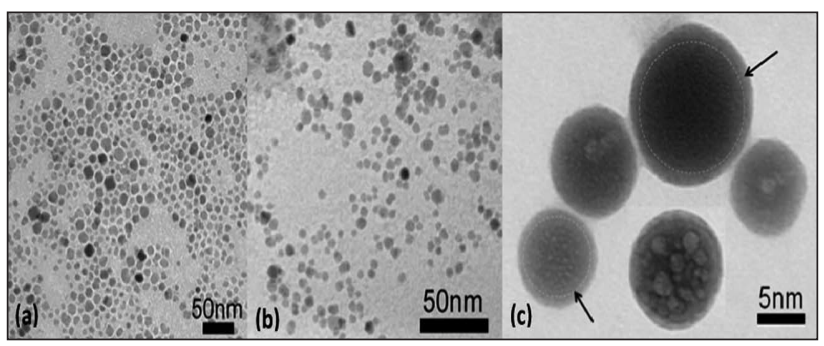

Fig. 5: TEM images of samples $\mathrm{CuO}-\mathrm{NPs}$ (a) $\mathrm{Cu}_{2} \mathrm{O}$ NPs (b) and (c) $\mathrm{Cu} / \mathrm{Cu}_{2} \mathrm{O}$ composite NPs

\section{CONCLUSIONS}

Nano $\mathrm{Cu}$ and Fe were gave a lot of opportunity for plant nutrient due to smart delivery system nanofertilzer more available as compassion to conventional fertilizer. Copper $(\mathrm{Cu})$ and iron $(\mathrm{Fe})$ nanoparticles were enhance crop productivity due to its improved the photosynthesis pigmentation and development much quantity of biomass. Nano $\mathrm{Cu}$ and $\mathrm{Fe}$ formulation using various agricultural area such as antifungal (nano fungicides) and antibacterial activity etc. Enzymatic activity of several crop were also influenced by the application of nano $\mathrm{Cu}$ and $\mathrm{Fe}$ due to more reactive specific surface area.

\section{REFERENCES}

Akhavan, O. and Ghaderi, E. 2010. Cu and CuO nanoparticles immobilized by silica thin films as antibacterial materials and photo catalysts. Surf. Coat. Technol., 205: 219-223.

Anthon, G.E., LeStrange, M. and Barrett, D.M. 2011. Changes in $\mathrm{pH}$, acids, sugars and other quality parameters during extended vine holding of ripe processing tomatoes. J. Sci. Food Agric., 91: 1175-1181.

Armin, M., Akbari, S. and Mashhadi, S. 2014. Effect of time and concentration of nano-Fe foliar application on yield and yield components of wheat. International Journal of Biosciences, 4: 69-75.

Boorboori, M.R., Asli D.E. and Tehrani, M.M. 2012. Effect of micronutrient application by different methods on yield, morphological traits and grain protein percentage of barley (Hordeum vulgare L.) in greenhouse conditions. Revista Científica UDO Agricola, 12(1): 127-134.

Cao, Y., Zhang, Y. and Ma, C. 2018. Growth, physiological responses, and copper accumulation in seven willow species exposed to $\mathrm{Cu}-\mathrm{a}$ hydroponic experiment. Environ. Sci. Pollut. Re., 25: 19875-19886.

Dimkpa, C.O., McLean, J.E., Latta, D.E., Manangon, E., Britt, D.W., Johnson, W.P., Boyanov, M.I. and Anderson, A.J. 2012. $\mathrm{CuO}$ and $\mathrm{ZnO}$ nanoparticles: phytotoxicity, metal speciation, and induction of oxidative stress in sandgrown wheat. J. Nanopart. Res., 14: 1125.

Giannousi, K., Avramidis, I. and Dendrinou-Samara, C. 2013. Synthesis, characterization and evaluation of copper based nanoparticles as agrochemicals against Phytophthora infestans. RSC Advances, 3(44): 21743.

Guerinot, M.L. and Yi, Y. 1994. Iron: nutritious, noxious and not readily available. Plant Physiol., 104: 815-820.

Hong, J., Rico, C.M., Zhao, L., Adeleye, A.S., Keller, A.A., Peralta-Videa, J.R. and Gardea- Torresdey, J.L. 2015. Toxic effects of copper-based nanoparticles or compounds to lettuce (Lactuca sativa) and alfalfa (Medicago sativa). Environ. Sci. Process Impact, 17: 177-185.

Jahanara, F., Sadeghi, M. and Ashouri, M. 2013. Effect of NanoIron (Fe) Fertilization and rhizobium leguminosarum on the qualitative and quantitative traits of Phaseolus vulgaris genotypes. In. J. Agri. Crop Sci., 5(6): 572-578.

Jones, J.B. 2007. Tomato Plant Culture: In the Field, Greenhouse, and Home Garden, $2^{\text {nd }}$ ed. CRC Press: Boca Raton, FL, USA.

Juarez-Maldonado, A., Ortega-Ortíz, H., Pérez-Labrada, F., Cadenas-Pliego, G. and Benavides-Mendoza, A. 2016. $\mathrm{Cu}$ Nanoparticles absorbed on chitosan hydrogels positively alter morphological, production, and quality characteristics of tomato. J. Appl. Bot. Food Qual., 89: 183-189. 
Karamanos, R.E., Pomarenski, Q., Goh, T.B. and Flore, N.A. 2004. The effect of foliar copper application on grain yield and quality of wheat. Canadian Journal of Plant Science, 84: 47-56.

Keller, A.A., Adeleye, A.S., Conway, J.R., Garner, K.I., Zhao, L., Cherr, G.N., Hong, J. and Gardea-Torresdey, J.L. 2017. Comparative environmental fate and toxicity of copper nanomaterials. Nano Impact, 7: 28-40.

Li, X., Gui, X., Rui, Y., Ji, W., Van Nhan, L., Yu, Z. and Peng, S. 2014. Bt-transgenic cotton is more sensitive to $\mathrm{CeO}_{2}$ nanoparticles than its parental non-transgenic cotton. Journal of Hazardous Materials, 274: 173-180.

Majumder, S. and Neogi, S. 2016. Antimicrobial activity of copper oxide nanoparticles coated on cotton fabric and synthesized by one-pot method. Adv. Sci., Eng. Med., 8: 102-111.

Mimmo, T., Del Buono, D., Terzano, R., Tomasi, N., Vigani, G. and Crecchio, R. 2014. Rhizospheric organic compounds in the soil-microorganism-plant system: their role in iron availability. Eur. J. Soil Sci., 65: 629-642.

Montes, M., Pierce, C.G., Lopez-Ribot, J.L., Bhalla, A.S. and Guo, R.Y. 2015. Properties of silver and copper nanoparticle containing aqueous suspensions and evaluation of their in vitro activity against Candida albicans and Staphylococcus aureus biofilms. J. Nanopart. Res., 37: 109-121.

Mushinskiy, A.A. and Aminova, E.V. 2019. Effect of iron, copper and molybdenum nanoparticles on morphometric parameters of Solanum tuberosum L. plants. IOP Conf. Series: Earth and Environmental Science, 341.

Nair, P.M.G. and Chung, I.M. 2014. Impact of copper oxide nanoparticles exposure on Arabidopsis thaliana growth, root system development, root lignificaion, and molecular level changes. Environ. Sci. Pollut. Res., 21: 12709-12722.

Nguyen, D.V., Nguyen, H.M., Le, N.T., Nguyen, K.H., Le, H.M., Nguyen, A.T., Dinh, N.T.T., Hoang, S.A. and Ha, C.V. 2020. Copper nanoparticle application enhances plant growth and grain yield in maize under drought stress conditions. https://doi.org/10.1101/2020.02.24.963132

Ogunkunle, C.O., Jimoh, M.A., Asogwa, N.T., Viswanathan, K., Vishwakarma, V. and Fatoba, P.O. 2018. Effects of manufactured nano-copper on copper uptake, bioaccumulation and enzyme activities in cowpea grown on soil substrate. Ecotoxicology and Environmental Safety, 155: 86-93.

Panigrahi, S., Kundu, S., Ghosh, S.K., Nath, S. \& Pal, T. 2004. General method of synthesis for metal nanoparticles. Journal of Nanoparticle Research, 6: 411-414.

Petzold, O.N., Schroeder J.F., Senaratne, W., Verrier, F. and Wei, Y. 2012. US Pat., 61532346

Rao, S. and Shekhawat, G.S. 2016. Phytotoxicity and oxidative stress perspective of two selected nanoparticles in Brassica juncea. Biotech, pp. 244. http://dx.doi.org/ 10.1007/s13205016-0550-3.

Rui, M., Ma, C., Hao, Y., Guo, J., Rui, Y., Tang, X. and Zhu, S. 2016. Iron Oxide Nanoparticles as a Potential Iron
Fertilizer for Peanut (Arachis hypogaea). Frontiers in Plant Science, 7.

Rui, M., Ma, C., Hao, Y., Guo, J., Rui, Y., Tang, X., Zhao, Q., Fan, X., Zhang, Z., Hou, T. and Zhu, S. 2016. Iron Oxide Nanoparticles as a Potential Iron Fertilizer for Peanut (Arachis hypogaea). Front. Plant Sci., 7: 815.

Shaw, A.K. and Hossain, Z. 2013. Impact of nano-CuO stress on rice (Oryza sativa L.) seedlings. Chemosphere, 93: 906-915.

Sheykhbaglou, R., Sedghi, M., Shishevan M.T. and Sharifi, R.S. 2010. Effects of Nano-Iron Oxide Particles on Agronomic Traits of Soybean. Not Sci. Biol., 2(2): 112-113.

Singh, A., Singh, N.B., Hussain, I. and Singh, H. 2017. Effect of biologically synthesized copper oxide nanoparticles on metabolism and antioxidant activity to the crop plants Solanum lycopersicum and Brassica oleracea var. botrytis. Journal of Biotechnology, 262: 11-27.

Trujillo-Reyes, J., Majumdar, S., Botez, C.E., Peralta-Videa, J.R. and Gardea-Torresdey, J.L. 2014. Exposure studies of core-shell $\mathrm{Fe} / \mathrm{Fe}_{3} \mathrm{O}_{4}$ and $\mathrm{Cu} / \mathrm{CuO}$ NPs to lettuce plants: are they a potential physiological and nutritional hazard. J. Hazard Mater, 267: 255-263.

Tyagi, S. 2016. Effects of Ascorbic Acid and Phenolic Content Concentrations on Natural Reduction of Silver Ions from Plant Extracts. Int. J. Curr. Microbiol. App. Sci., 5(11): 885890.

Usepa, U. 2007. Nanotechnology White Paper. Prepared for the US Environmental Protection Agency by Members of the Nanotechnology Workgroup, a Group of Epa's Science Policy Council Science Policy Council (pp. 20460). Washington, DC: US Environmental Protection Agency.

Vargas, E.L., Ortega-Ortiz, H., Cadenas-Pliego, G., de Alba Romenus, K., Cabrera de la Fuente, M., BenavidesMendoza, A. and Juarez-Maldonado, A. 2018. Foliar application of copper nanoparticles increases the fruit quality and the content of bioactive compounds in tomatoes. Applied Sciences, 8(7): 1020.

Viera, I., Perez-Galvez, A. and Roca, M. 2019. Green natural colorants. Molecules, 24. https:/doi.org/10.3390/ molecules24010154

Wang, Y., Lin, Y., Xu, Y., Yin, Y., Guo, H. and Du, W. 2019. Divergence in response of lettuce (var. ramosa Hort.) to copper oxide nanoparticles/microparticles as potential agricultural fertilizer. Environ. Pollut. Bioavailab., 31: 80-84.

Ye, L., Li, L., Wang, L., Wang, S., Li, S., Du, J. and Shou, H. 2015. MPK3/MPK6 are involved in iron deficiency-induced ethylene production in Arabidopsis. Frontiers in Plant Science, 6. doi:10.3389/fpls.2015.00953

Zargar, S.M., Agrawal, G.K., Rakwal, R. and Fukao, Y. 2015. Quantitative proteomics reveals role of sugar in decreasing photosynthetic activity due to Fe deficiency. Frontiers in Plant Science, 6. doi:10.3389/fpls.2015.00592

Zuo, Y. and Zhang, F. 2011. Soil and crop management strategies to prevent iron deficiency in crops. Plant and Soil, 339(1-2): 83-95. 